\title{
HYPERBARIC TREATMENT OF CEREBRAL AIR EMBOLISM: A REPORT OF A CASE FOLLOWING CARDIAC CATHETERIZATION*
}

\author{
R. K. Calverley, M.D., W. A. Dodds, M.D., W. G. Trapp, M.D., C.M., F.R.C.S., \\ AND L. C. JENKINS, M.D., C.M., F.R.C.P. (c)
}

\begin{abstract}
CFrfBral AIR EMBolism is an uncommon, but potentially catastrophic complication of some diagnostic and therapeutic surgical procedures. Obstruction of the cerebral arteries by an air embolus can precipitate an acute ischaemia of the tissue distal to the site of the block. The severity of the insult depends upon the location and size of the ischaemic area. Cerebral manifestations can include coma, convulsions, blindness, hemiplegia, quadraplegia, aphasia or minor localizing signs. Recovery may occur spontaneously, but death or severe permanent disability may be the legacy of this misadventure.

The preferred treatment is prompt application of hyperbaric therapy to diminish the size of the gas embolus and oxygen therapy to increase the diffusion gradient for nitrogen from the air bubble. Oxygen therapy also increases the oxygen diffusion gradient to the periphery of the ischaemic area.

Since there are few reports of the application of this definitive treatment in the clinical literature, the following case report is presented to demonstrate an application of this technique in the Hyperbaric Research Unit of the Vancouver General Hospital.
\end{abstract}

\section{Case Report}

A four-month-old infant with the presumptive diagnosis of a ventricular septal defect underwent cardiac catheterization in the investigation of congestive heart failure. The anaesthetized patient received halothane, nitrous oxide and oxygen by mask, while a catheter was introduced through the right femoral vein and positioned in the right ventricle. A pressure pump connected in preparation for bi-plane angiography was activated. The staff members watching the video screen were horrified to realize that the injection syringe had not been filled. Ten cubic centimeters of air were injected into the ventricle and left the heart through the aorta and pulmonary artery. Before the cardiologist could attempt to aspirate any of the air, it had passed beyond the heart and the great vessels.

The infant immediately demonstrated extreme bradycardia and apparent bronchospasm. Anaesthesia was terminated. The patient was intubated and ventilated with oxygen while atropine $0.1 \mathrm{mg}$ was injected intravenously. During the period of resuscitation, the cardiac rate and ventilation improved. The patient was extubated and "screamed lustily."

On arrival at the hyerbaric chamber thirty-five minutes after the injection of air, the patient was alert, but anxious, irritable and screaming. One observer

"From the Department of Anaesthesiology and the Hyperbaric Research Unit of the University of British Columbia. 
thought that the cry was unusually pitched; another physician recorded diminished movement of the right lower limb. Liebermeister's sign, the presence of areas of pallor on the tongue after air embolism, was not observed. Retinal examination was not performed prior to hyperbaric therapy.

An anaesthetist and a nurse accompanied the infant in the chamber which was immediately pressurized to 6 atmospheres absolute ( 6 ATA), 5 atmospheres above ambient pressure. A slow, staged 5-hour decompression was initiated after 15 minutes at 6 ATA. During decompression the child demonstrated normal social and motor responses and was eager to nurse. Neurological examination was also normal. Oxygen was not used during decompression as there was concern that high oxygen tensions might precipitate convulsions in a patient who had apparently recovered completely. At the completion of therapy the infant demonstrated no neurological deficit.

Three days after hyperbaric therapy one episode of "arching" was observed by a nurse, but no other neurological abnormalities were apparent during the following month before discharge. The patient underwent surgery without further investigation procedures. At the time of the pulmonary banding the lesion was recognized as a corrected transposition of the great vessels with a ventricular septal defect.

The infant was treated as a case of cerebral air embolism although it was recognized that the signs of distress may have been related entirely to air in the pulmonary artery. Air could be seen in the aorta, however, and it is probable that some passed up the carotid vessels. In the presence of signs of cerebral irritation and a questionable partial monoplegia, the management of this patient fulfills the dictum that even when the diagnosis is in doubt, time and hyperbaric therapy are much less expensive than is the loss of central nervous system tissue. ${ }^{1}$

\section{Review and Discussion}

Since cerebral air embolism may occur in several situations where an anaesthesiologist may be responsible for the patient's management, we shall review the surgical procedures where this risk is present and discuss the pathophysiology and management of this condition.

\section{SuRgical Hazards}

Cerebral arterial air embolism may occur as a result of the introduction of air into the pulmonary veins, left atrium, left ventricle, proximal aorta or carotid arteries. Some of these common clinical situations with a risk of accidental air embolus warrant individual review.

(1) Cerebral arteriography. Air may be directly injected into the vertebral or carotid arteries if any air is present in the syringe. ${ }^{2}$

(2) Cardiac Surgery. Cerebral air embolism is a recognized hazard of open heart surgery, especially during the insertion and removal of the aortic cannula. Air may also remain in the left atrium or ventricle when these chambers are closed at the end of the repair. The incidence of cerebral air embolism during cardiac 
surgery is unknown, but this should be considered in the assessment of any patient demonstrating a neurological deficit after cardiopulmonary bypass. ${ }^{3,4}$

(3) Cardiac Catheterization and Arterial Pressure Lines. Both reservoir bags and injectors constitute a hazard.

All of the air must be evacuated from the reservoir bag which contains the solution used to clear blood from the catheter tip or air may enter the catheter and be injected into the chambers of the heart.

The injector employed in angiography injects a measured volume of dye. Failure to fill the injector or to evacuate all air from the injector places the patient in peril. The case report which we have presented demonstrates the need for continual vigilence.

(4) Thoracic Surgery. If a pulmonary vein with a subatmospheric internal pressure is opened during surgical dissection of the lung, air may be drawn into the vessel and be discharged into the systemic circulation. ${ }^{5}$

(5) Pneumothorax Therapy. This abandoned procedure was a cause of cerebral air embolism. ${ }^{6}$

\section{Paradoxical Air Embolism}

A systemic venous air embolus may pass through a patent foramen ovale or an atrial or ventricular septal defect if the pressure gradient permits right to left flow at the time when the air enters the heart. This mechanism has been the cause of cerebral air embolism following criminal abortion. ${ }^{7}$

Other causes of paradoxical air embolism include the introduction of air into a subclavian vein catheter. Ponsky and Pories $^{8}$ describe a fatality in a convalescent, ambulatory patient caused by the aspiration of air into a disconnected central venous pressure catheter. The patient collapsed and was comatose for three days before death. At autopsy a large patent foramen ovale was found and “... the brain demonstrated multiple and diffuse areas of recent white-matter demyelinization and infarction, without any sign of vascular occlusion."?

While an experimental study by Emerson et al. ${ }^{10}$ has not demonstrated transpulmonary passage of a systemic venous air embolus from the pulmonary artery to the pulmonary veins, this observation has been challenged recently.

Professor Guy Vourc'h reports, "Two cases show that this is not always true. In the first, air embolism occurred during a neurosurgical procedure in the sitting position. The surgeon could see air bubbles in the cerebral arterioles. Careful autopsy failed to show any cardiac defect. Secondly, during the surgical removal of a large thoracic aneurysm, profuse bleeding necessitated massive transfusion by means of a mechanical pump. Some air was sucked into the perfusion tubing through a minute leak; during cardiac massage, air bubbles were seen in the coronary arteries. No cardiac defect was seen at autopsy."11

\section{RAPid Decompression}

"Burst lung" is a complication of submarine escape exercises and scuba diving. After respiration of air under pressure, lung volumes expand during rapid ascent. Intra-pulmonary pressures will rise unless a continuous forceful expiration is 
maintained. Areas of partial bronchial obstruction create a ball-valve effect or segmental hyperinflation, which predisposes to rupture. ${ }^{12}$ If the transpulmonary pressure gradient exceeds $50 \mathrm{~mm}$ of mercury, ${ }^{13}$ normal alveoli may rupture into the pulmonary interstitium, the pleural space or the pulmonary veins. From the pulmonary vein, the embolus will traverse the chambers of the left side of the heart to enter the aorta and may ascend the carotid arteries to the cerebral circulation since the diver is commonly upright during ascent. ${ }^{14}$

Cerebral air embolism is a recognized cause of accidental death among scuba divers. The frequency of this catastrophe is difficult to determine as the air may not be demonstrable unless the pathologist is aware of this possibility. ${ }^{15}$ Death from coronary artery air embolism has occurred following uncontrolled ascent from a depth of only nine feet of water. ${ }^{10}$

\section{Pathophysiology}

Arterial air embolism can create an obstruction to flow in the small arteries and arterioles. The emboli are also endothelial irritants which produce ischaemic effects exceeding those caused from mechanical obstruction alone. ${ }^{17}$ Temporary segmental arteriolar spasm has been described to occur over a period of some minutes; the affected vessels then dilate, but stasis persists. At an unpredictable rate gas emboli may pass through capillaries from the arteries to the veins. This has been demonstrated in several tissues including the retina, ${ }^{18}$ the meninges, ${ }^{19}$ and the coronary circulation. ${ }^{20}$ However, air may remain in the arterial circulation for many hours. ${ }^{21}$

\section{Experimental Studies}

Experimental bronchovenous fistulae have been produced in guinea pigs by increasing the intratracheal pressure. At airway pressures of $55 \mathrm{~mm} \mathrm{Hg}$ and greater, alveoli ruptured into adjacent blood vessels with subsequent convulsions and death. Air was demonstrated in the coronary and cerebral arteries at autopsy. ${ }^{22}$

The potential complication of cerebral air embolism during open heart surgery led Fries et al ${ }^{23}$ to study the effects of injection of air into the cerebral circulation of dogs. It was found that 1.5 and 3 cubic centimeters of air per kilogram of body weight produced profound cerebral disturbances, including convulsions. Areas of cortical infarction were seen in those animals sacrificed forty-eight hours later. Gas bubbles could still be demonstrated in the pial vessels at that time. Surviving animals demonstrated permanent neurological deficits.

The first experimental study employing hyperbaric therapy was conducted in 1963. Meigne et al..$^{24}$ injected air into the carotid arteries of rabbits and showed a remarkable improvement in the survival rate of the group treated with hyperbaric oxygen. In a similar experimental study Iwa et al. ${ }^{25}$ demonstrated that improvement was seen even after delaying treatment for four hours after the injection of air.

\section{Principles of Therapy}

The established principles of treatment are applications of Boyle's Law and Fick's Law. 
Compression reduces bubble volume as defined in Boyle's Law since volume is inversely proportional to pressure. There is a corresponding, but lesser, decrease in the diameter of the embolus since the diameter varies as the cube root of the volume. Compression beyond 6 ATA results in relatively small changes in embolus volume and increase the potential hazard of inert gas narcosis in chamber personnel.

Fick's Law can be applied to relate the rate of nitrogen diffusion to the concentration gradient between the bubble and the surrounding tissue. Denitrogenating the tissues will improve the rate of diffusion of nitrogen from the bubble. One hundred per cent oxygen may be employed for this purpose during decompression but only at pressures of 3 ATA or less due to its toxic effects on the central nervous system at higher pressures.

\section{I) JeTERIOUS EFFECTS}

While hyperbaric therapy and oxygen therapy are advantageous, two deleterious influences on the treatment are the effect of nitrous oxide and the transportation of the patient in aircraft.

Nitrous oxide diffuses rapidly into enclosed pockets of gas causing an increase in pressure or an increase in volume if the surrounding tissues permit expansion of the bubble. This has received attention as a complication of air encephalography during nitrous oxide anaesthesia. ${ }^{26}$ The same effect has been demonstrated in experimental pulmonary artery air embolism ${ }^{27}$ and is a significant factor in the management of cerebral air embolism.

While increased pressure has a therapeutic effect, decreased pressure is harmful as the embolus expands. Travel in unpressurized aircraft is particularly hazardous. Commercial jet aircraft are partially pressurized to a cabin altitude of 2,000 to 8,000 fect above sea level.

\section{Mititary Experience with Ceribral Air Embolism}

Before World War II, the navies of the United States of America and other countries had developed recompression as the treatment for cerebral gas embolism sustained in submarine escape exercises. ${ }^{28}$ From 1946 until 1962 recompression was successfully employed on forty-six occasions in the u.s. Navy centers. ${ }^{29}$ The original treatment tables took 19 to 38 hours to complete in order to diminish the risk of decompression sickness as a result of protracted exposure to air at 6 ATA.

In 1968 the United States Navy modified their initial treatment programme for a cerebral air embolus (Figure 1). The current management employs rapid compression to six ATA which provides mechanical reduction of bubble dimensions. If the patient responds favourably after 10 to 20 minutes at this pressure, chamber pressures are reduced to 3 ATA. One hundred per cent oxygen can be used intermittently or continuously during the remainder of the decompression, which may be carried out in stages as demonstrated in the diagram or by a continuous gradual reduction of pressure. This treatment programme reduces the hazard of decompression sickness and permits a shorter period of decompression. ${ }^{30}$

\section{Civilian Experience with Cerebral Air Embolism}

In the past, when military hyperbaric chambers were often at a considerable 


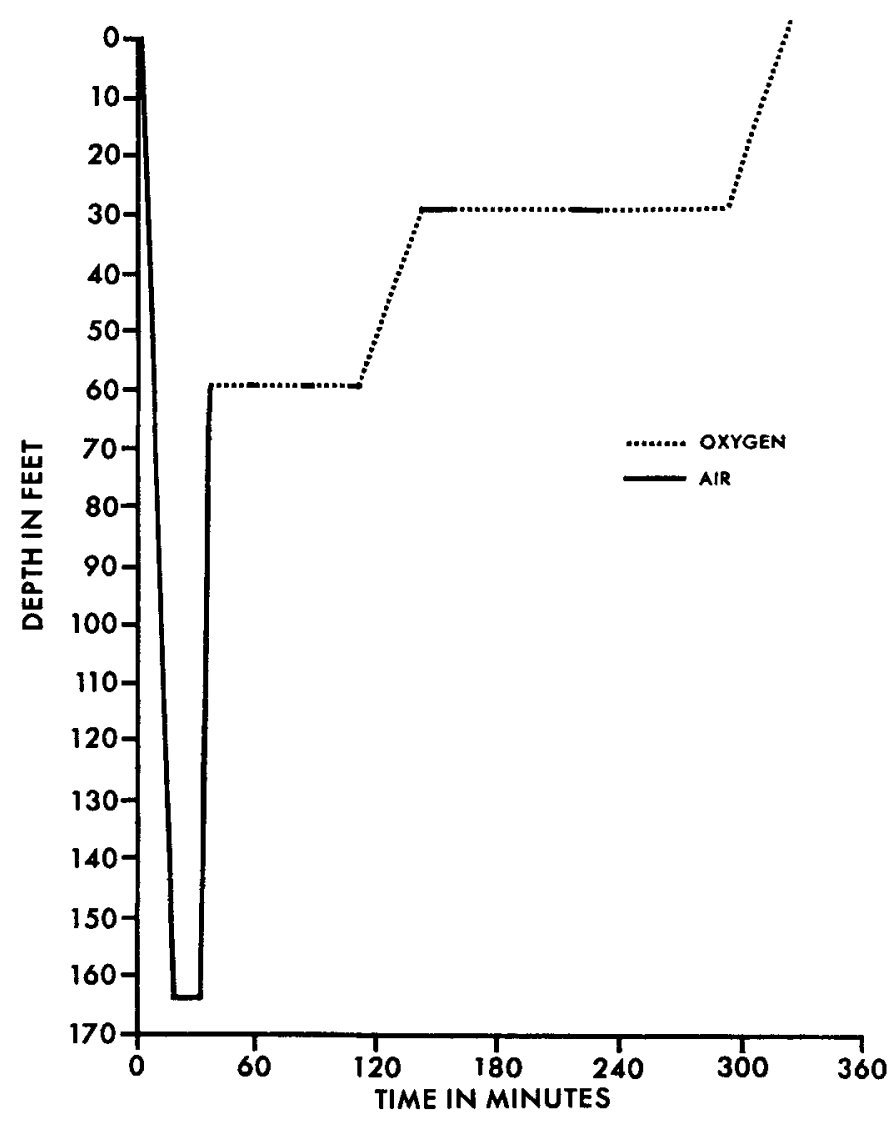

Figure 1. Oxygen breathing method for treatment of decompression sickness and air embolism.

distance from civilian hospitals, clinicians have concentrated upon the prophylaxis of arterial air embolism. A head-down tilt is employed during decannulation. Some cardiac surgeons flood the operative field with carbon dioxide since this more soluble gas is likely to have only transient effects as a gas embolus. These techniques are of prophylactic value only. The only common therapeutic manœuver has been to provide the patient with 100 per cent oxygen to breathe to hasten reabsorption of the bubble.

The diagnosis of cerebral air embolism has been based upon the occasional observation of air entering the systemic arterial circulation or, more commonly, upon the recognition of an acute neurological deficit following surgery. Since identical neurological sequelae may follow embolization with particulate matter, it may be impossible to make a definite diagnosis postoperatively without a trial of hyperbaric therapy.

Michael Price of Memorial University has suggested a diagnostic aid which may be of value when employed during cardiac surgery. ${ }^{31} \mathrm{~A}$ Doppler Flowmeter has 
been demonstrated to be a sensitive device capable of detecting the turbulence caused by the passage of minute venous air emboli. ${ }^{32}$ Price has suggested that this instrument could be placed over the carotid arteries during cardiac surgery. To our knowledge this suggestion has not yet been applied clinically.

\section{Hyperbaric Therapy following Cardiac Surgery}

The first case report in the clinical literature was presented by Takita et al. ${ }^{33}$ from Buffalo, N.Y. in 1968. They described the successful management of a patient who suffered a cercbral air embolus caused by the accidental flushing of air into an aortic cannula during mitral valve replacement. Prior to hyperbaric therapy she demonstrated a left hemiplegia. Six and one-half hours after the embolus entered her aorta she was treated at a depth of 6 ATA. During decompression, sensation and motor power improved. At the time of discharge from hospital she had "no detectable residual defect."

P.M. Winter ${ }^{34}$ has reviewed this case and two others which were treated in the hyperbaric chamber of the same hospital (Table I). In each case, massive air embolism had been observed during open-heart surgery. One patient, a young man, was quadraplegic and apparently blind before the treatment which began four hours after embolization. His recovery was complete. A child was not treated until 11 hours after the acute episode and was admitted comatose and convulsing. She showed improvement but was still aphasic when Winter's report was presented one month later.

TABLE: I

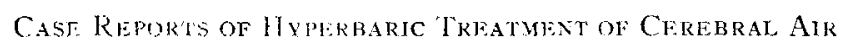
EMBOLTSM

\begin{tabular}{lcc}
\hline \hline Pre-treatment condition & $\begin{array}{c}\text { Delay before } \\
\text { therapy }\end{array}$ & $\begin{array}{c}\text { Residual } \\
\text { deficit }\end{array}$ \\
\hline 1. Hemiplegia & $6 \frac{1}{2}$ hours & None \\
2. Quadraplegia & 4 hours & None \\
3. Coma and convulsions & 11 hours & Aphasia \\
\hline
\end{tabular}

\section{The Eatergency Managhanent of Cerebral Atr Exibolus}

The prevention of ccrebral air emboli demands continuous vigilance in every clinical situation where this complication may occur.

If a cerebral air embolus should occur or be suspected as a result of misadventure or human error, several important steps can be instituted.

1. Nitrous oxide anaesthesia should be discontinued.

2. The patient should be ventilated with oxygen.

3. Standard resuscitation is employed as indicated.

4. If the incident occurs during surgery, the procedure should be terminated as quickly as possible.

5. After anaesthesia the patient should be assessed. If there is any evidence of acute neurological deficit, cerebral air embolus should be considered. In some puzzling cases, hyperbaric therapy may resolve a diagnostic dilemma and be therapeutic at the same time. 


\section{HYPERBARIC FACILITIES}

At present there are only three civilian hyperbaric units in Canada which are adequately equipped as pressurized intensive care units. These are located in Toronto, Montreal, and Vancouver. Military chambers are situated in Victoria, Halifax, and Toronto.

When a patient sustains a cerebral air embolus in a center at some distance from these widely scattered units clinical management depends upon the condition of the patient. The unconscious patient who may require emergency assistance cannot be adequately treated in the non-transportable one-man chambers which might be available in some provinces.

If the patient is sufficiently responsive to permit transportation to a hyperbaric unit, the hazard of expansion of the embolus during flight can be overcome and therapy administered more promptly, by requesting a Canadian Forces transportable chamber. These one-man units are stationed at Esquimalt, Toronto, and Halifax and may be dispatched by air at any hour with an experienced medical flight team to any part of Canada (Table II).

TABLE II

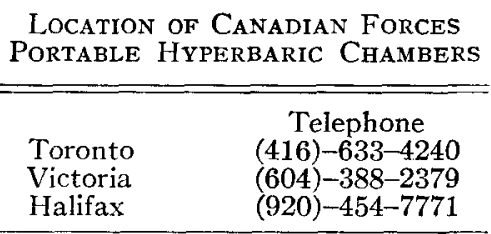

The patient is isolated from the staff during transport, but this chamber does provide an opportunity for continuous hyperbaric treatment for the conscious patient en route to a more sophisticated facility. On arrival, the mobile chamber is brought into the larger unit which is then pressurized and the patient transferred without interruption of therapy.

\section{SUMMARY}

Hyperbaric medicine provides the definitive treatment for cerebral air embolism. First consideration must be given to the prevention of this complication in every situation where the patient may be exposed to this hazard. Once an embolus has occurred, supportive measures should be instituted promptly. If possible, the patient should be transferred to a hyperbaric unit. Experimental and clinical evidence demonstrate that remarkable improvement may follow hyperbaric therapy, even when there is a delay of several hours before treatment is initiated.

\section{RÉSUMÉ}

L'embolie gazeuse est une complication plutôt rare; elle peut devenir une complication catastrophique de certaines opérations pour traitement ou pour diagnostic. L'obstruction des artères cérébrales par de l'air peut provoquer une ischémie aiguë des tissus en périphérie du site du blocage. L'intensité des dommages peut 
dépendre de la localisation du territoire jschémié mais ausi de son étendue. La guérison peut se faire spontanément, mais la rançon d'une telle mésaventure peut ètre la mort ou une incapacité permanente grave.

L'embolie gazeuse cérébrale peut survenir à la suite de l'entrée d’air dans les veines pulmonaires, l'oreillette gauche, le ventricule gauche, l'aorte proximale et les artères carotides. Une semblable complication peut survenir au cours de la chirurgie cardiaque, du cathétérisme cardiaque, de l'artériographie cérébrale et de la chirurgie thoracique.

Une embolie gazeuse paradoxale peut survenir lorsque survient une embolie gazeuse dans une veine systémique et qu'il existe, chez le malade, une communication interauriculaire ou interventriculaire. Deux histoires de cas récentes nous laissent croire qu'une embolie gazeuse paradoxale peut survenir même s'il n'y a pas de perforation septale démontrable.

L'embolie gazeuse cérébrale est une éventualité possible lors de la décompression rapide au cours de la plongée sousmarine ou lors des exercices de sortie d'un sousmarin.

Le: traitement définitif consiste dans lapplication précoce de la thérapie hyperbare pour réduire le volume de l'embolus et la thérapie à l'oxygène pour accroître la vitesse de diffusion de l'azote contenu dans l'embolus. Cette thérapie a été mise à point par des médecins de la marine et elle a été employée par la médecine sousmarine depuis au delà de 30 ans. Des études expérimentales ont confirmé la valeur d'un tel traitement.

La thérapie hyperbare a été employée avec succès dans le traitement de trois cas d'embolie gazeuse cérébrale à la suite de chirurgie cardiaque. Notre histoire de cas raconte le traitement d'un enfant qui a reçu une injection intra-cardiaque de $10 \mathrm{ml}$ d'air au cours d'un cathétérisme cardiaque.

Actucllement, il existe seulement trois unités civiles de chambre hyperbare au Canada qui sont adéquatement outillées comme l'exige une unité de soins intensifs. Elles sont situées à Toronto, Montréal et Vancouver. Les chambres militaires sont situées à Victoria, Halifax et Toronto.

Lorsqu'un malade vient d'avoir une embolie gazeuse cérébrale dans un endroit un peu éloigné de ces unités dispersées, la conduite du traitement peut varier selon létat du malade. Si le malade demeure conscient et transportable, il est possible d'instituer la thérapie hyperbare durant le transport en demandant aux forces canadiennes une chambre transportable pour un homme. Ces unités sont stationnées à Victoria, à Toronto et à Halifax et peuvent être dirigées par air à tout endroit au Canada avec une équipe volante d'expérience pour prendre soin du malade durant le trajet vers un centre plus élaboré.

En résumé, la médecine hyperbare constitue le traitement définitif de l'embolie gazeuse cérébrale.

\section{REFERENCES}

1. Lanphier, E. H. Fundamentals of Hyperbaric Medicine, Washington, D.c., Nat. Acad. Sc. Nat. Res. Council Publication 1298, p. 102 (1966).

2. Honowitz, N. H. \& Rizzolı, H. V. Postoperative Complications in Neurosurgical Practice. Baltimore, The Williams and Wilkins Co., p. 332 (1967).

3. Allen, P. Central Nervous System Emboli in Open Heart Surgery. Canad. J. Surg., 6: 332 (1963). 
4. Nicks, R. Arterial Air Embolism. Thorax, 22: 320 (1967).

5. Chase, W. H. Anatomical and Experimental Observations on Air Embolism. Surg. Gynee. \& Obst., 59: 569 (1934).

6. Schattenberg, H. J. \& Zrskin, J. Air Embolism as a Complication of Artificial Pneumothorax. Am. J. Clin. Path., 9: 477 (1939).

7. Rapin, M.; Goulon, M. \& Jouailhat, F.: Four Cases of Post Abortal Neurologic Accident Treated with Hyperbaric Oxygenation. Proc. of Third Int. Conf. on Hyperbaric Med., 1965, Washington, DC, Nat. Acad. Sc. Nat. Res. Council of Washington, nC (1966).

8. Ponsky, J. L. \& Ponies, W. J. Paradoxical Cerebral Air Embolism (correspondence) 9. Ibid. N. Engl. J. Med., 284: 985 ( 1971).

10. Emerson, L. V.; Hempleman, H. V.; \& Lentle, R. G. Passage of Gaseous Emboli through the Pulmonary Circulation. Resp. Physiol., 3: 213 (1967).

11. Vourc'H, G. Paradoxical Air Embolism (correspondence). N. Engl. J. Med., 285: 56 (1971).

12. Smith, F. R. Air Embolism as a Cause of Death in Scuba Diving in the Pacific Northwest. Dis. Chest, 52: 15 (1967).

13. Kmn, D. J. Personal Communication.

14. Lanphier, E. Management of Sports Diving Accidents. Ny State J. Med., 63: 667 (1963).

15. Sмith, F. R. Dis. Chest, 52: 15 (1967).

16. Cooperman, E. M.; Hogg, J.; \& Thurlbeck, W. M. Mechanism of Death in ShallowWater Scuba Diving. Canad. M. A. J., 99: 112 (1969).

17. Chase, W. H. Surg. Gynec. \& Obst., 59: 569 (1934).

18. Wong, R. T. Air Emboli in the Retinal Arteries. Report of a case. Arch. Ophth., 25: 149 (1941).

19. Fries, G. C.; Levowitz, B.; Adler, S.; Cook, A. W.; Karlson, K. E.; \& Dennis, C. Experimental Cerebral Gas Embolism. Ann. Surg., 145: 461 (1957).

20. Rakstinat, G. Experimental Air Embolism of the Coronary Arteries. J.A.M.A., 96: 26 (1931).

21. Pollock, M. Air Embolus. Am. Rev. Tubuc., 28: 187 (1933).

22. Rukstinat, G. \& LeCount, E. R. Air in Coronary Arteries. J.A.M.A., 91 : 1776 (1928).

23. Fries, C. C. Ann. Surg., 145: 461 (1957).

24. Meijne, N. G.; Schoemaker, G.; \& Bulterijs, A. B. The Treatment of Cerebral Gas Embolism in a High Pressure Chamber. An Experimental Study. J. Cardiovas. Surg., 4: 757 (1963).

25. Iwa, T.; Feld, E. H.; \& Weinberg, M. Effects of Hyperbaric Oxygen Therapy on Cerebral Air Embolism. (Abstract) Dis. Chest., 50: 333 (1966).

26. Saidman, L. J. \& Eger, E. I. Change in Cerebrospinal Fluid Pressure During Pneumoencephalography Under Nitrous Oxide Anaesthesia. Anaesthesiology, 26: 67 (1965).

27. Munson, E. Effect of Nitrous Oxide on the Pulmonary Circulation During Venous Air Embolism. Paper presented at 45th Congress of the International Anaesthesia Research Society - March (1971).

28. us Navy Diving Manual. Navships 250-538, Washington, DC. us Government Printing Office (1963).

29. Rrvera, J. C. \& Dennison, W. L. Gas Embolism and Related Accidents. Diving Medicine Notebook. Groton, Connecticut, Naval Submarine Medical Centre, p. 203 ( 1966 ).

30. Van Genderen, L. \& Waite, C. L. Treatment of Traumatic Cerebral Air Embolism. Aerospace Med., 39: 709 ( 1968 ).

31. Price, M. J. Personal Communication.

32. Edmonds-Seal, J. \& Maroon, J. C. Air Embolism Diagnosed with Ultrasound Anaesthesia, Anaesthesia, 24: 438 (1969).

33. Takita, J. H.; Olszewskr, W.; Schimert, G.; \& Lanphier, E. H. Hyperbaric Treatment of Cerebral Air Embolism as a Result of Open-Heart Surgery. J. Thorax. Cardiovasc. Surg., 55: 682 (1968).

34. Winter, P. M.; Gage, A. A.; \& Alvis, H. J. Cerebral Air Embolism Occuring During Cardiopulmonary Bypass Treated with Hyperbaric Oxygenation. Report of Three Cases. Proceedings of the Fourth International Congress on Hyperbaric Medicine, Tokyo, Igaku Shoin Ltd, p. 360 ( 1970). 